\title{
Twin Deficits Hypothesis and Capital Mobility: The ASEAN-5 Perspective
}

\author{
Ahmad Zubaidi Baharumshah \\ Hamizun Ismail \\ Evan Lau
}

ABSTRACT

This paper investigates the relevance of the twin deficits hypothesis (TDH) in five Association of Southeast Asian Nations (ASEAN) countries. We examine the causal relation between current account deficits, budget deficits and investments. The empirical findings may be summarised as follows. First, TDH holds only for three countries: Malaysia, Thailand and the Philippines. In other words, a budget deficit plays a significant role in the determination of a current account deficit in all the three countries. Second, the findings are in line with the widely held view that government expenditure crowds out private investment. Third, investment shows a noticeable impact on current account deficits. Finally, a high proportion of domestic investment is financed from international sources, which suggests that the Feldstein-Horioka puzzle is less important in these emerging economies.

ABSTRAK

Kertas ini mengkaji kepentingan hipotesis defisit berkembar untuk lima buah negara ASEAN. Kertas ini meneliti perkaitan sebab-menyebab di antara defisit akaun semasa, defisit belanjawan, dan pelaburan. Penemuan-penemuan kertas ini boleh diringkaskan seperti berikut: Pertama, hipotesis defisit berkembar tidak ditolak bagi tiga buah negara, iaitu Malaysia, Thailand dan Filipina. Kedua, penemuan dalam kertas ini selari dengan hujah yang menyatakan bahawa perbelanjaan kerajaan memberi kesan himpitan keluar kepada pelaburan. Ketiga, pelaburan membawa kesan yang ketara terhadap defisit akaun semasa. Keempat, sebahagian besar pelaburan domestik dibiayai oleh sumber-sumber luar, dan dengan itu menyokong pernyataan bahawa teka-teki Feldstein-Horioka tidak begitu penting bagi negara-negara membangun yang dikaji dalam kajian ini.

\section{INTRODUCTION}

Over the past three decades, a twin deficits hypothesis has been a topic of interest in the empirical literature. The causal link between public budget deficits and current account balances is frequently a subject of analysis. This is largely due to its important implication on a nation's long-term economic progress. From a theoreti- 
cal perspective, fiscal expansion could worsen both current account balances and the appreciation of the real exchange rate (Salvatore 2006). The imbalances could impair economic activity, undermine wealth creation and reduce the well being of a nation. From a policy perspective, it is well known that if rising current account deficits are indeed due to escalating fiscal deficits, then the external balance cannot be remedied unless policies that address government deficits are first put in place. Nonetheless, the existing literature on the question over whether budget deficits matter in the major OECD countries has been far from conclusive (Seater 1993).

In the late 1970s, many developing countries were running very large budget deficits to finance large and growing government spending. To finance these deficits, governments borrowed heavily in global capital markets. This borrowing happened either directly from international banks or indirectly by issuing bonds to foreign investors. The large and growing budget deficits led to large current account deficits and the accumulation of a very large stock of foreign debt. By 1982, the size of this public foreign debt was so large that it often would reach close to or above $100 \%$ of the gross domestic product (GDP). Many countries experienced difficulties in repaying interest and/or principal on their foreign liabilities, and by the end of 1987 the total external debt of less developed countries exceeded one trillion US dollars. What followed was a severe debt crisis in the early 1980s. Many developing countries risked default on their foreign debt and had to renegotiate a rescheduling for their foreign liabilities.

There are cases, however, where current account deficits have been associated with a strong and thriving economy. In the context of foreign capital-led growth, capital inflows help to lift savings and investment constraints on growth. In such cases, national savings are not sufficient to finance all new profitable investment projects. It is sometimes necessary for a country to run a current account deficit and rely on foreign savings to finance the savings-investment gap. Over time, the goods produced by the new capital will lead to increased exports earnings that will eventually generate trade and the current account surpluses necessary to repay foreign debt and the interest on it. Hence, current account deficits and foreign debt accumulation generated by an investment boom might actually increase the rate of a country's economic growth where domestic savings are not sufficient.

Large fiscal deficits accompanied by widening trade deficits, as witnessed in many countries in recent years, have motivated increasing research on these issues. In the context of ASEAN countries, both fiscal deficits and current account balances have taken dramatic turns since the landmark 1997 financial crisis. For example, Malaysia experienced a sequence of budget surpluses averaging $0.80 \%$ of the GDP per year over the 1993-1997 period and was accompanied by a sequence of current account deficits averaging $4.59 \%$ of the GDP per year. The situation, however, reversed after 1997 when Malaysia recorded fiscal deficits between 1998 and 2001 (averaging $4.04 \%$ per year) while its current account balance was in successive surpluses (averaging 10.38\% per year). Indonesia, the Philippines and Thailand have also encountered similar experiences, but the extent of the problem varies across these countries. 
The lack of a positive correlation between budget deficits and current account deficits during the post-crisis period may be explained as follows. The ASEAN countries under investigation went through several quarters of recession in the aftermath of the 1997 financial crisis. During this period, ASEAN countries record a fall in output and a worsening of fiscal balance due to an "active budget" deficit that arises from expansionary fiscal policy. Measurements show improvement in current accounts as the fall in output leads to a decline in investment that is larger than the changes in private and national savings. Thus, fiscal balance worsens and external balance improves. The pattern that emerged in the past few years seems to reflect more of a twin divergence than a twin deficit. The evidence documented in Salvatore (2006), however, suggest that lagged budget deficit is the single most important determinant of a current account.

The purpose of this article is to empirically assess the effects of budget deficits on current account deficits and the investment in five ASEAN countries (the ASEAN-5 includes Indonesia, Malaysia, Singapore, Thailand and the Philippines). The focus is primarily on the effect of a budget on current account deficits. This is the socalled twin deficits hypothesis. The analysis is conducted within the framework of cointegration analysis, error correction modeling and Granger non-causality test. This article contributes to the current literature in several ways. First, we consider a model that includes both budget deficits and investment as the determinants of the current account, while the bulk of the empirical studies emphasize either one of these two factors. The error correction model offers support to the Keynesian proposition by examining one-way causality from budget deficits (BD, hereafter) to current account deficits (CAD, hereafter). The approach adopted in this study enables us to provide further evidence on the degree of capital market integration in the region.

Second, by focusing on the ASEAN-5 countries that generally share common experiences, especially in the state of infrastructure and the regulations of financial sectors, the investigation may also contribute to the formulation of appropriate policies that are related to budget and current account deficits. It is worth mentioning that the bulk of the literature on the impact of budget deficits on current account deficits and other macro variables relies heavily on the US and other developed countries. The experiences of the emerging market economies (ASEAN, in particular) are very different from that of large industrialized nations with large and highly developed capital markets. It is often argued that for the developed economies, private savings and investment may absorb the BD without having a significant impact on the external balance. For a large country like the US, fiscal expansion may lead to an increase in interest rates and this increase may crowd out private investment and at the same time stimulate private savings. Thus, a worsening of BD may not worsen a current account (private investment) in the US. This is inline with a number of studies that have suggested that the impact of BD should be judged relative to the size of the economy. Hence, there is a need for further investigation on the issue using data from other smaller economies during this period of imbalance in the global economy. 
The rest of this paper is organized as follows. The next section briefly reviews some of the relevant literature. Section 3 provides a brief review of the analytical framework of the study. Section 4 describes the methodology adopted as well as the data used in the analysis, and Section 5 details the empirical results. Finally, Section 6 summarises the major findings and provides some policy implications.

\section{REVIEW OF THE LITERATURE}

The wide variety of empirical results shows that the impact of budget deficits on macroeconomic variables is controversial and theoretically ambiguous. In this section, we focus on the relationship between BD and CAD and we show how BD may affect domestic investment. The TDH asserts that an increase in BD will result in a similar increase in CAD. Various theoretical studies of this issue have resulted in many contrary views, especially on the causal relation between BD and CAD.

The first theoretical insight on the relation between BD and CAD is based on the popular Mundell-Fleming (MF, hereafter) framework. The approach argues that an increase in BD induces an upward pressure on interest rates that, in turn, will trigger capital inflows, which will ultimately lead to an increase in CAD. A second theoretical model that is also commonly used to connect the two deficits is based on the Keynesian absorption theory. The theory asserts that a rise in $\mathrm{BD}$ would induce domestic absorption and, hence, it would lead to import expansion and deterioration in CAD.

One contrary view on the relation between $\mathrm{BD}$ and CAD is based on the presumption that the two deficits are not related at all. Such a view is known as the Ricardian equivalence hypothesis (REH, hereafter) and is advanced by Barro (1989). REH predicts that an increase in BD must be paid for either now or later, with the total present value of receipts fixed by the total present value of spending. As Barro (1989) puts it, "a decrease in the government's saving (that is, a current budget deficit) leads to an offsetting increase in desired private saving, and hence to no change in desired national saving. Since desired national saving does not change, the real interest rate does not have to rise in a closed economy to maintain balance between desired national saving and investment demand."

The REH is of course not without objection on both theoretical and empirical grounds. There is no unanimity in the results on the acceptance or rejection of REH. Bernheim (1989), for example, raises questions regarding certain assumptions about the consumer behavior used to support the Ricardian hypothesis. Using the US data on the 1980s period, Gramlich (1989), among others, shows that private saving, relative to net national product, fell together with the decline in federal saving. This result contradicts the REH perspective that suggests the private saving rate should have increased sufficiently to offset the decline in federal saving during that period. Although REH may not hold empirically, some authors have argued that the proposition is a reasonable approximation of the reality (Seater 1993). 
The literature on the effects of BD on investment can be classified into three distinct schools of thought: Neoclassical, Keynesian and the REH. As mentioned earlier, the REH asserts that shifts between taxes and budget deficits do not matter for the real interest rate, the quantity of investment or the current account balance. On the other hand, the Neoclassicals consider individuals planning their consumption over their entire life cycle. By shifting taxes to future generations, budget deficits increase current consumption. If the economy is operating at full employment, then an increase in consumption implies a decrease in saving. Interest rates must then rise to bring capital markets into balance. Higher interest rates, in turn, result in a decline in private investment. Meanwhile, the Keynesian perspective portrays the expansionary effects of budget deficits. Under this view, a significant fraction of the population is thought of as either myopic or liquidity constrained. As Bernheim (1989) explains it, "appropriately timed deficits have beneficial consequences."

In our brief review of the literature, we find that the empirical evidence on the $\mathrm{BD}$ and CAD is at best mixed. Zietz and Pemberton (1990) examine the US data to find that BD affects the CAD mainly through its impact on domestic absorption and income rather than through higher interest and exchange rates. In contrast, Abell (1990) also examine the US data but contends that the causation runs from the BD deficit through the interest rate and the exchange rate to the CAD. In this empirical work, Abell emphasizes that there is no direct link between the two deficits. Authors such as Bahmani-Oskooee (1995), Khalid and Teo (1999), Piersanti (2000) and others also found evidence that there is a significant link between BD and CAD mainly through the interest and exchange rate channels. Fidrmuc (2003), using data from ten OECD countries, two emerging countries and six transition economies, confirms the twin-deficits hypothesis but with some noticeable differences between the results of the 1980s and those of the 1990s. Similarly, Bagnai (2006) finds that the hypothesis holds for a large number of OECD countries. By considering the impact of structural breaks, Bagnai points out that financial integration is increasing in most OECD countries, including the non-EU economies.

Mohammadi (2004) finds that bond-financed government expenditure has a greater effect on the current account balance than tax-financed expenditure. On the other hand, Rahman and Mishra (1992) and Bachman (1992) all find evidence not in favor of the TDH. Kaufmann et al. (2002) and Kulkarni and Erickson (2001) also find no connection between the two deficits in Austrian and Mexican data, respectively. While most of the studies mentioned above focus on the experience of the industrialised nations such as the G-7, little attention has been given to developing economies. Among the few exceptions are Islam (1998) who examine the Brazilian data, Anoruo and Ramchander (1998) who examine India, Indonesia, Malaysia, Korea and the Philippines, Khalid and Teo (1999) who examine India, Indonesia, Pakistan and Egypt, and recently Kouassi et al. (2004) who examine the data of 10 selected developing economies. An important point made by the above-mentioned authors is that the underlying dynamic relation between the twin deficits in the developing world may vary across countries due to the disparity in their macroeconomic structure. 
The empirical evidence on BD and investment is also mixed. One popular approach is to study the effect of government expenditure on economic growth. Recent articles by Argimon et al. (1997), Bahmani-Oskooee (1999) and Ahmed and Miller (2000), among others, support the existence of a significant crowdingin effect of private investment on public expenditure. In addition, Miller and Russek (1997) emphasize that the effects of government expenditure on economic growth are dependant on both the method of financing and the components of the expenditure. In contrast, Nelson and Singh (1994) find that the budget deficits exercised little if no impact of any statistical significance on economic growth in less developed countries during the 1970s and 1980s. However, Bagnai (2006) finds a stable long-run relationship between current account, fiscal deficit and investment in 22 OECD countries. It turns out that investment has a positive impact on CAD, and this suggests that investment booms seem depressed when externally balanced. Therefore, on the whole, the empirical evidence on the link between BD and investment is inconclusive.

\section{THE ANALYTICAL FRAMEWORK}

The framework of national accounts defines a clear link between budget deficits and current accounts. We begin with private savings, $S^{p}$, which is defined as disposable income (income less taxes), $Y-T$, minus private consumption, $C$, and public (government) savings, $S^{g}=T-G$, which is defined as the difference between direct taxes for households and firms, $T$, and public expenditures, $G$. By adding private and public savings, we obtain

$$
S_{t}^{p}+S_{t}^{g}=\left(Y_{t}-C_{t}-T_{t}\right)+\left(T_{t}-G_{t}\right)=Y_{t}-\left(C_{t}+G_{t}\right)=S_{t}^{n}
$$

where $S^{n}$ is national savings. Then, by using the national income account identity,

$$
Y_{t}=C_{t}+I_{t}+G_{t}+N_{t} \text {, }
$$

where $I$ is the investment and $N$ is the net export, national savings can be written as

$$
S_{t}^{m}+Y_{t}=\left(C_{t}+G_{t}\right)=C_{t}+I_{t}+G_{t}+N_{t}-C_{t}-G_{t}=I_{t}+N_{t}
$$

The current account balance, $C A$, is defined as "payment received from abroad in exchange for currently produced goods and services, minus the analogous payments made to foreigners by the domestic economy". Hence, in the simplest case, the current account can be taken to be equal to net exports. Rearranging the national savings equation, the current account can be written as national savings minus investment. Further, replacing $N$ with $C A$ and substituting for $S^{n}$, we obtain

$$
C A_{t}=S_{t}^{p}-I_{t}-\left(G_{l}-T_{i}\right) \text {. }
$$

Eq. (4) provides a convenient framework to examine the relationship between the government deficit, $G-T$, and the current account deficit. If private saving is roughly equal to investment $\left(S^{p} \approx l\right)$ as in Bagnai (2006) and Fidrmuc (2003), then 
the $\mathrm{BD}$ and the $\mathrm{CAD}$ are directly interrelated. In other words, the external account and the fiscal balance, labeled the twin deficits, have to move in the same direction by the same amount.

Next, we look for a long-run relationship between the current account and the fiscal balances. The current account identity states that the current account has to equal the capital and financial account, that is

$$
C A_{t}=B_{t+1}-B_{t} .
$$

$B$ is the beginning of period real net stock of outstanding foreign assets (debts if negative). It follows that accumulated current $\sum^{\tau} C_{A_{i}}=\sum^{\tau}{ }_{B_{i+1}}-B_{i}$ o external debt associated with a particular period $\pi, \sum_{i=1} C_{i}=\sum_{i=1}^{t} B_{i+1}-B_{i}$. As we can see from this equation, external debts generate a continuous flow of interest payment and possibly a repayment or debt rescheduling some time in the future (Fidrmuc 2003). Therefore, a country has to meet all these liabilities by means of current account surpluses (i.e. export surpluses) if required. The current account has to be sustainable not only at a particular point in time; rather, the whole trajectory of the current account has to be considered. Besides illustrating the current account as a long-run phenomenon, this argument also highlights the importance of making a distinction between investment-induced and consumption-induced current account deficits because only the former raise productivity and export capacity in the long-run.

Recent studies show that the public sector may meet their financing needs by both domestic and international financial markets (Fidrmuc 2003; Bagnai 2006). Taking into consideration the significant role of private investment in the context of intertemporal approach to the balance of payment as discussed above, the long-run relationship between the $\mathrm{CAD}, \mathrm{BD}$ and investment can be written as

$$
C A D_{t}=\beta_{1}+\beta_{2} B D_{t}+\beta_{3} I_{t},
$$

where $C A D$ is the current account deficit (i.e., $C A D=-C A$ ) and $B D$ is the budget deficit $(B D=T-G)$. Eq. (6) provides a useful framework for investigating the link between $C A D, B D$ and $I$. As indicated by Eq. (6), we expect the coefficients of both budget deficits and investment to be positive (Fidrmuc 2003). That is, a BD and a high domestic investment are expected to worsen the current account. Corresponding to this equation, the existence of large and highly sophisticated capital markets in developed countries makes it possible for these countries to finance both public and private domestic needs through capital markets. Therefore, we expect a high correspondence between the $\mathrm{CAD}$ and the $\mathrm{BD}$ in the long run. High correspondence between the CAD and I is more likely to occur in developing countries than the developed ones. Specifically, the coefficient of budget deficit should equal one if the country is perfectly integrated into the world economy. Meanwhile, if the coefficient of investment is equal to unity, then it suggests that the country's investment expenditures are totally financed through the world financial market. 


\section{DATA AND STATISTICAL STRATEGY}

We investigated the long-run relationship and causality between current account, fiscal balance and investment for the ASEAN-5 countries. Specifically, the vectorerror correction models (VECMs) were deployed to determine the long-run behaviour and the causal relation among the variables in the system, namely current account deficit, budget deficit and investment.

The annual data of current account deficits, budget deficits and investments for the period spanning from 1960 to 2003 were used in our analysis. In particular, for Indonesia and Singapore, the period only started from 1969 and 1963 respectively, because the data for budget deficit and current account prior to these years were not available. The annual series for budget deficit to GDP ratio, BD, were taken from International Monetary Fund's International Financial Statistics (IFS) up to the year 1995, and from the ASEAN Finance and Macroeconomic Surveillance Unit (FMSU) database from the year 1996 onward. Up to the year 2000, the investment to GDP ratio series, $I$, were obtained from the Penn World Table (PWT) published by University of Pennsylvania's Center for International Comparison, whereas for the years 2001-2003, the ratio was calculated as the ratio of the gross-fixed capital formation to the GDP, taken from the IMF's International Financial Statistics (IFS).

In order to construct the series for current account deficit to GDP ratio, CAD/ GDP, we collected the annual series of private consumption to GDP ratio (C/GDP), domestic investment to GDP ratio (I/GDP), government expenditure to GDP ratio (G/ GDP), and gross national product to GDP ratio (GNP/GDP) from the PWT. The current account to GDP ratio, CAD/GDP, was then calculated as (GNP/GDP)-(C/GDP)-(I/GDP)-(G/ GDP). For the years 2001-2003, the current account to GDP ratios were from the IFS.

The exact forms of our models and the appropriate tests for a short-run and longrun causal relation will depend critically on the order of integration of each variable and cointegration properties of each system in the 5-country sample. We started by testing the stationary properties of each variable. To accomplish this, we employ the augmented Dickey-Fuller (ADF) and the Phillips-Perron (PP) tests on the null hypothesis of nonstationarity. In addition, we also used the Kwiatkowski-PhillipsSchmidt-Shin (KPSS: Kwiatkowski et al. 1992) test that is based on stationary null.

After testing for stationarity, we applied the Johansen's trace and maximumeigenvalue $(\lambda$-max $)$ tests to determine whether the variables in each system were cointegrated, and if so, how many cointegrating vectors would be identified from the system. Cheung and Lai (1993) suggest that the trace test shows more robustness to skewness and excess kurtosis in the residual rather than the maximum-eigenvalue test. It is also robust to departures from heteroskedasticity (Johansen 1995). Enders (1995), on the other hand, suggests that the maximum-eigenvalue test has a sharper alternative hypothesis than the trace test and should be preferred in deciding the number of cointegrating vectors. Since all these procedures are widely used in the literature, we do not describe them in this paper.

A finding of cointegration indicates that there is a stable long-run relation among the variables in the system. More importantly, the VECM representation can 
only be pursued if the variables in system are cointegrated. Specifically, the VECM representation takes the form

$$
\begin{aligned}
\triangle C A D_{t}= & \alpha_{1}\left(C A D_{t-1}-\beta_{0}-\beta_{1} B D_{t-1}-\beta_{2} I_{t-1}\right)+\sum_{i=1}^{k-1} \lambda_{1, j} \Delta C A D_{-i} \\
& +\sum_{i=1}^{k-1} \delta_{1,} \Delta B D_{t-i}+\sum_{i=1}^{k-1} \gamma_{1, i} \Delta I_{t-i}, \\
\Delta B D_{t}= & \alpha_{2}\left(C A D_{t-1}-\beta_{0}-\beta_{1} B D_{t-1}-\beta_{2} I_{t-1}\right)+\sum_{i=1}^{k-1} \lambda_{2, i} \Delta C A D_{-i} \\
& +\sum_{i=1}^{k-1} \delta_{2, i} \Delta B D_{t-i}+\sum_{i=1}^{k-1} \gamma_{2, i} \Delta I_{t-i},
\end{aligned}
$$

and

$$
\begin{aligned}
\Delta_{t}= & \alpha_{3}\left(C A D_{t-1}-\beta_{0}-\beta B D_{t-1}-\beta_{2} I_{t-1}\right)+\sum_{i=1}^{k-1} \beta_{, i} \Delta C A D_{t-i} \\
& +\sum_{i=1}^{k-1} \delta_{3, i} \Delta B D_{t-i}+\sum_{i=1}^{k-1} \gamma_{3, i} \Delta I_{t-i},
\end{aligned}
$$

where $\alpha_{i}$ is the coefficient of the error-correction term (ECT), and $\beta_{i}$ is the coefficient of the cointegrating equation of the system. The parameters of the ECT measure the response of each of the dependent variables in each period to the departure from equilibrium condition. Convergence is assured if $\alpha_{i}$ is between 0 and -1 . The statistical significance of the coefficient on the error-correction term can be used to investigate the weak exogeneity of the dependant variable.

A significant coefficient on the error-correction term indicates the dependant variable responses to any deviation from the system's stationary long-run path. On the other hand, an insignificant coefficient on the error-correction term suggests that the dependant variable does not adjust in the long run to any perturbations in the system. Second, the sign of each coefficient in the cointegrating vector represents the direction in which each variable moves in response to deviations in the stationary linear combination (i.e., the error-correction term) that stabilizes the model. Third, the coefficients $\lambda_{i}, \delta_{i}$ and $\gamma_{i}$ can be linked to the short-run causality (i.e. Granger causality) relation of the variables with respect to the dependant variable. For example, a negative and significant $\gamma_{i}$ indicates that investment positively causes a current account deficit in the short-run.

\section{EMPIRICAL RESULTS}

The first step in the analysis is to pre-test each variable to determine the order of integration. To this end, we relied on the standard ADF and PP tests first on the 
levels and then on their first differences. Additionally, we deploy the KPSS tests in order to arrive at conclusive evidence on the stationarity of the variables under investigation. The null hypotheses for an ADF test and a PP test is that a certain series has a unit root. In contrast, the null hypothesis for a KPSS test is constructed under the null that the series under investigation is a stationary process. The optimal lag lengths for ADF tests and the KPSS tests are chosen based on the Schwarz information criterion (SIC), while the bandwidths for the PP tests are determined by the Newey-West method.

The results of the unit root tests are displayed in Table 1. Three types of unit root tests are carried out in this study. It is obvious that the ADF and the nonparametric PP tests failed to reject the null hypothesis of a unit root for all series at the 5\% significance level. Similarly, the KPSS tests rejected the null hypothesis of stationarity for all cases, except for Malaysia's $I$ series. Notice that for the case of Malaysia's I series, the ADF and PP tests provided strong evidence that the series is an $I(0)$, except for the KPSS test. To sum up, the combined results from all the unit root tests performed suggest that all series under consideration (CAD, $B D$ and I) appear to be an $I(1)$ process.

Having verified that we cannot reject that all variables are $I(1)$, the next step is to perform the Johansen test for cointegration in order to determine whether there are stable long-run relations between budget deficits, current account deficits and investments. To implement the Johansen's procedure, we determine the optimum lag in the VAR model. There are various criteria designed to aid in choosing the order of a VAR model. Our choice is based on the Akaike's information criterion (AIC) and the Schwartz's criterion (SBC). The residuals from the selected VAR were also checked for whiteness. If the residuals in any equation proved to be autocorrelated, we sequentially chose a higher lag until there was no evidence of autocorrelation. The selection procedure led to the choice of one lag for Malaysia and the Philippines, two lags for Thailand and three lags for Indonesia and Singapore.

Two types of tests are suggested in the Johansen-Juselius test. We perform both the trace tests and maximum eigenvalue tests by assuming that (1) there is a linear trend in the data and (2) there is an intercept but no trend in the cointegrating equation. Results of the Johansen test are shown in Table 2. The outcomes of the cointegration test indicate that there exists cointegration in the system for Malaysia and Philippines at lag length equal to one (VAR [1]). For Singapore and Thailand, a unique vector is detected at VAR [3] and VAR [2], respectively. The JohansenJuselius test fail to reject the null hypothesis of no cointegrating relationship for the Indonesian data. We re-examined the existence of cointegration in the system at a higher lag order (up to VAR [5]), and the results (not reported) failed to reject the null at the usual significance levels. As such we conclude that there is no evidence to support a long-run relation between $C A D, B D$ and $I$.

Cheung and Lai (1993) suggest that trace test shows more robustness to skewness and excess kurtosis in the residuals rather than maximum eigenvalue test. Further, the LR test for Johansen are derived from asymptotic results and statistical inference in the finite sample may be inappropriate. They point out that the null 
TABLE 1 . The unit root test

\begin{tabular}{|c|c|c|c|c|c|c|}
\hline \multirow[t]{2}{*}{ Country } & \multicolumn{2}{|c|}{$\mathrm{ADF}$} & \multicolumn{2}{|c|}{ Phillips-Perron } & \multicolumn{2}{|c|}{ KPSS } \\
\hline & $\begin{array}{c}\text { Levels } \\
\text { differences }\end{array}$ & First & $\begin{array}{c}\text { Levels } \\
\text { differences }\end{array}$ & First & $\begin{array}{c}\text { Levels } \\
\text { differences }\end{array}$ & First \\
\hline \multicolumn{7}{|c|}{ Budget deficit (BD) } \\
\hline Indonesia & -3.1192 & $-6.2471 *$ & -3.1192 & $-7.3926^{*}$ & $0.2852 *$ & 0.0154 \\
\hline Malaysia & -2.1564 & $-6.7666^{*}$ & -2.6835 & $-6.6141 *$ & $1.5446^{*}$ & 0.0235 \\
\hline Philippines & -3.4034 & $-8.2469 *$ & -3.4034 & $-8.2469 *$ & $0.2016^{*}$ & 0.0334 \\
\hline Singapore & -2.4863 & $-3.6185^{*}$ & -3.0136 & $-12.4286^{*}$ & $0.2689 *$ & 0.1275 \\
\hline Thailand & -2.6174 & $-5.3192 *$ & -2.1361 & $-5.3192 *$ & $1.0298 *$ & 0.0660 \\
\hline \multicolumn{7}{|c|}{ Current account deficit (CAD) } \\
\hline Indonesia & -3.3983 & $-6.5765^{*}$ & -3.3983 & $-7.6541 *$ & $0.2862 *$ & 0.0155 \\
\hline Malaysia & -2.6150 & $-5.9746^{*}$ & -2.6150 & $-5.9746^{*}$ & $0.6954 *$ & 0.0312 \\
\hline Philippines & -2.9777 & $-7.2579 *$ & -2.9777 & $-7.2579 *$ & $0.5456^{*}$ & 0.0239 \\
\hline Singapore & -2.2277 & $-5.7841 *$ & -1.8483 & $-6.3915^{*}$ & $2.0232 *$ & 0.0491 \\
\hline Thailand & -2.0669 & $-3.6900^{*}$ & -2.0669 & $-5.9954 *$ & $1.2806^{*}$ & 0.0354 \\
\hline \multicolumn{7}{|c|}{ Investment (I) } \\
\hline Indonesia & 0.1762 & $-6.6000 *$ & 0.1762 & $-6.6000^{*}$ & $3.3890 *$ & 0.1289 \\
\hline Malaysia & -0.8911 & -1.7910 & -0.8911 & $-10.8650^{*}$ & $1.2022 *$ & $0.4317^{*}$ \\
\hline Philippines & -1.0423 & $-5.7657^{*}$ & -1.0423 & $-5.7657^{*}$ & $1.6834^{*}$ & 0.0628 \\
\hline Singapore & -1.0310 & $-7.3402 *$ & -1.0310 & $-7.3402 *$ & $3.1666^{*}$ & 0.0358 \\
\hline Thailand & -1.0494 & $-5.7607 *$ & -1.0494 & $-5.7607^{*}$ & $1.6826^{*}$ & 0.0625 \\
\hline
\end{tabular}

Notes: (1) In all of the tests, we assume that the data have a constant and a linear trend. All the lag values and bandwidths are determined by Eviews- 5

(2) The lags for ADF tests were chosen based on the SIC, while the bandwidths for the PP and KPSS tests were based on the Newey-West method

(3) The asterisk $(*)$ indicates that the statistics are significant at $5 \%$ level

hypothesis of non-cointegration is often rejected (known as size distortion). We employ the Reinsel-Ahn scaling factor (T-nk)/T and multiplied it to the original test statistic. The results of the Johansen tests indicate that the null hypothesis is not rejected even if the size distortion is revised and that a long run relationship holds among the three variables. To summarize, the two LR tests yield similar results and thus provide evidence to reject the null hypothesis of zero cointegrating vectors in favor of one cointegration vector at 5\% significance level in all the countries under investigation except Indonesia. In the case of Indonesia, we find no evidence for TDH as long-run phenomenon.

Next, we address the question of whether all the variables in Eq. (6) enter in the long-run equilibrium relationship. This test can easily be executed by applying zero restriction on each of the long-run coefficients after they have been normalised on the variable of interest (in our case $C A D$ ). The exclusion of each variable is tested using an LR test that is asymptotically distributed as $\chi^{2}$ with a degree of freedom equal to the number of restrictions tested. The test statistics (not reported) for each variable exceeds the critical value, which means that both $B D$ and investment $(I)$ 
TABLE 2. The Johansen-Juselius cointegration test

\begin{tabular}{|c|c|c|c|c|c|}
\hline $\begin{array}{l}\text { Country } \\
\text { Results }\end{array}$ & Lags & $\mathrm{H}_{0}: \mathrm{No} \mathrm{CE}$ & $\mathrm{H}_{0}:$ At most $1 \mathrm{CE}$ & \multicolumn{2}{|l|}{$\mathrm{H}_{0}:$ At most $2 \mathrm{CE}$} \\
\hline \multicolumn{6}{|c|}{ Model: CAD, BD, I } \\
\hline \multicolumn{6}{|c|}{ The trace test: trace statistics (p-value) } \\
\hline Indonesia & 3 & $20.0780(0.4176)$ & 5.611436 & $0.193468(0.6600)$ & $0 \mathrm{CE}$ \\
\hline Malaysia & 1 & $41.7188(0.0014) *$ & $13.97230(0.0837)$ & $3.388784(0.0656)$ & $1 \mathrm{CE}$ \\
\hline Philippines & 1 & $34.4542(0.0135) *$ & $13.12835(0.1102)$ & $2.695122(0.1007)$ & $1 \mathrm{CE}$ \\
\hline Singapore & 3 & $41.6755(0.0014)^{*}$ & $10.20070(0.2656)$ & $0.945867(0.3308)$ & $1 \mathrm{CE}$ \\
\hline Thailand & 2 & $33.1692(0.0197) *$ & $8.553160(0.4083)$ & $0.002530(0.9575)$ & $1 \mathrm{CE}$ \\
\hline
\end{tabular}

The maximum eigenvalue test: maximum eigenvalue statistic ( $\mathrm{p}$-value)

$\begin{array}{lccccc} & & \mathrm{H}_{0}: \text { No CE } & \mathrm{H}_{0}: \text { At most 1 CE } & \mathrm{H}_{0}: \text { At most 2 CE } & \\ \text { Indonesia } & 3 & 14.46658(0.3280) & 5.417969(0.6884) & 0.193468(0.6600) & 0 \mathrm{CE} \\ \text { Malaysia } & 1 & 27.74648(0.0051) * & 10.58351(0.1764) & 3.388784(0.0656) & 1 \mathrm{CE} \\ \text { Philippines } & 1 & 21.32584(0.0470) * & 10.43323(0.1850) & 2.695122(0.1007) & 1 \mathrm{CE} \\ \text { Singapore } & 3 & 31.47484(0.0013) * & 9.254836(0.2656) & 0.945867(0.3308) & 1 \mathrm{CE} \\ \text { Thailand } & 2 & 24.61601(0.0155) * & 8.550630(0.3255) & 0.002530(0.9575) & 1 \mathrm{CE}\end{array}$

Notes: (1) Asterisk (*) denote statistically significant at the 5\% level

(2) Maximum eigenvalue and trace statistics are compared to with the critical value with those in Johansen and Juselius (1990, Table 2)

enter in the long-run equilibrium relationship with $C A D$. Thus, $B D$ and $I$ share a common stochastic trend with $C A D$ in the countries under investigation. Put differently, although deviations from equilibrium could occur, they are rather mean-reverting. Since we do not find any significant cointegrating vectors for Indonesia, our focus now is on the other four ASEAN economies: Malaysia, Singapore, Thailand and the Philippines.

Given the evidence in favor of cointegration, we then estimate the long-run parameters of the model. Normalising on $C A D$, the Johansen-Juselius procedure provides the long-run equation for the current account. Table 3 displays the long-run (cointegrating) equation of each country along with their $t$-statistic in brackets. The normalized equation shows that both coefficients of budget deficit and investment are positive; that is, the current account deteriorates with a budget deficit and high investment. Notice that the coefficient of investment $(I)$ is in a plausible range carries the expected sign (positive) and is statistically significant. The magnitude of the coefficient ranges from 0.51 (Singapore) to 1.03 (Thailand), indicating that a high proportion of their domestic investment is financed from international sources. For the case of Thailand, the estimated coefficient for investment is close to unity, which means that the whole investment amount is financed from international sources.

Using the LR test, we formally test the null hypothesis that the coefficient of the investment $(I)$ is unity. The test statistic is asymptotically distributed as $\chi^{2}$ with one degree of freedom. The outcome of this test is reported in the last column of Table 3. According to the test results, the null cannot be rejected at the conventional 
significance levels in all cases, which means that they are insignificantly different from unity. This finding seems in line with the argument that capital markets in the ASEAN economies are fully integrated with the global economy. In other words, all of them actively participate in world capital markets. Therefore, the FeldsteinHorioka puzzle does not seem to hold for the four ASEAN countries. It is worth noting that Fidrmuc (2003) and Blanchard and Giavazzi (2003), among others, present similar evidence for the European countries.

The reported coefficients for the $B D$ are all statistically significant at the $5 \%$ level or better in all but one case (the Philippines). The magnitude of the coefficient for Singapore is unexpectedly high (3.04). It is worth noting that a recent article by Fidrmuc (2003) also finds the coefficient in some European countries to be relatively high in the 1990s (e.g. for France it is 16.71). Interestingly, the LR statistics reported in the second last column of Table 3 failed to reject the null: $H_{0}: \beta_{2}=1$, including the case of Singapore. Therefore, like domestic investment, the budgetary expenditure in the emerging ASEAN economies (except perhaps for the Philippines) is financed largely by world capital markets. The extent to which these countries depend on the global capital market for domestic investment may vary across the countries in the sample as indicated by the individual coefficients.

The VECM provides the long-run error-correction behavior and the short-run causality among the variables in the system as well. The error-correction term captures the long-run relation while the short-run dynamics are captured by the lagged differences, and conventional tests of causality may be based on the significance of these terms. A question often raised in the literature is that "is there a causal relationship in a Granger sense between $C A D$ and $B D$ ?" If it does, does it run from $B D$ to $C A D$ or the other way round? Table 4 shows that the error-correction term in the $\triangle C A D$ equation is significant at $5 \%$ level for Malaysia and Philippines

TABLE 3. Cointegrating equations and the restriction test

\begin{tabular}{lcccccc}
\hline Country & \multicolumn{3}{c}{ Cointegrating equation $(t$-value $)$} & \multicolumn{3}{c}{$\begin{array}{c}\text { LR-test } \chi^{2} \text {-statistics } \\
(p \text {-value })\end{array}$} \\
& & & & & \multicolumn{2}{c}{${ }^{2}$} \\
& $\mathrm{CAD}$ & $\mathrm{BD}$ & $\mathrm{I}$ & $\mathrm{C}$ & $\mathrm{H}_{0}:{ }^{2} \grave{\mathrm{A}}_{2}=1$ & $\mathrm{H}_{0}:{ }^{2} \grave{\mathrm{A}}_{3}=1$ \\
\hline Malaysia & -1.000 & 0.3705 & 0.5763 & -0.1459 & 1.7389 & 2.2766 \\
& $(1.8829)^{*}$ & $(4.8186)^{*}$ & & $(0.1873)$ & $(0.1313)$ & \\
Philippines & -1.000 & 0.4919 & $0.5386^{*}$ & -0.0698 & 1.8291 & 0.8628 \\
& & $(1.2198)$ & $(3.8048)$ & & $(0.1762)$ & $(0.3529)$ \\
Singapore & -1.000 & 3.0381 & 0.5162 & -0.1567 & 1.8049 & 0.0376 \\
& & $(7.9647)^{*}$ & $(2.5889)^{*}$ & & $(0.1791)$ & $(0.8462)$ \\
Thailand & -1.000 & 0.5786 & 1.0292 & -0.1228 & 3.4722 & 1.1141 \\
& & $(2.4811)^{*}$ & $(5.6066)^{*}$ & & $(0.0624)$ & $(0.2912)$ \\
\hline
\end{tabular}

Notes: (1) Cointegrating equation is normalized on CAD for vector [CAD, BD, I]. Normalization is conducted if nonzero vector or vectors are confirmed by the cointegration test

(2) The figures in the parentheses below the coefficient are the $t$-statistics

(3) The asterisk (*) indicates that the statistics are significant at $5 \%$ levels 
and at the $10 \%$ level for Thailand. Our results show that $C A D$ is endogenous in three countries: Malaysia, Thailand and the Philippines. As revealed in Table 3, it is $C A D$ that adjusts its path to the long-run equilibrium in all these ASEAN countries.

The evidence further supports the notion that $B D$ and $I$ Granger-cause $C A D$ in the long-run. More importantly, these findings imply that there is one-way causality between $C A D$ and $B D$ for Malaysia, Philippines and Thailand since the errorcorrection term with $\triangle B D$ is not significant even at $10 \%$ level for all three cases. For Malaysia and Thailand, we identify an additional channel (indirect) between the two variables through investment $(I): B D \rightarrow \triangle I \rightarrow C A D$. For Singapore, we find that $C A D$ Granger-causes $B D$ in the long run, but not the other way around. Thus, although we find that $C A D$ and $B D$ developed along a joint path, the causal relation between the two variables does not seem to support the Keynesian view (that is, $B D \rightarrow C A D$ in the case of Singapore). With regard to Singapore, it bears noting the issue in the 1990s and early 2000s is not one of large current account deficits but rather large surplus. The current account surplus in 1996 (a year before the Asian crisis) amounted to about $20 \%$ of the GDP.

For the $B D$ equation, the coefficient of the error-correction term is significant only for Singapore. For the three other countries, the coefficient of the error-correction term is statistically insignificant at conventional levels. This finding implies that $B D$ plays a weakly exogenous role in the $C A D$ equation. This is an important finding because it implies that fiscal policy is an effective tool to influence current account balance in the ASEAN countries like Malaysia, Thailand and the Philippines. Finally, in the investment equation, the coefficients of the error-correction term are significant for Thailand, Malaysia and Singapore at the $10 \%$ level or better in all except the Philippines. Therefore, in the case of Philippines, both $B D$ and $I$ play a weakly exogenous role (the error correction terms are insignificant). In the other four countries, the evidence shows that investment adjusts to any deviation in the system's equilibrium. The empirical results appear to suggest that $B D$ has a negative effect on $I$ in the long-run. Hence, our finding confirms the neoclassical view that government expenditure crowds out private investment. We view this as a new finding and worth noting. Unlike the US, there is no evidence to indicate that capital inflows act as a force to mitigate the problem of crowding out in the smaller ASEAN economies

The VECM also provides us with some additional information on the short-run causality among all the variables in the system. Specifically, short-run dynamics are provided by the lagged values of the difference terms. Table 4 shows the results of the Wald-test. We use this test to decide whether the null hypothesis shows that a particular variable does not Granger-cause the dependant variable in the shortrun. The results show that there is no short-run relation in both ways between $B D$ and $C A D$ at conventional significance levels. The results also do not indicate any short-run relation in both ways between $B D$ and $I$ at the 0.05 level, with the sole exception of Thailand where the result suggests that $B D$ does Granger-cause $I$. As for the $C A D-I$ relation, our finding shows that $I$ Granger-causes $C A D$ for the case of 
Philippines, and that $C A D$ Granger-causes $I$ for Thailand. This, as well as the other causal relations are displayed in Table 4.

\section{SUMMARY AND CONCLUSION}

In this paper, we examine the relationship between current accounts, budget deficits and investments in the ASEAN-5 countries for which very little empirical evidence exists. All in all, our data seems to support the twin deficits hypothesis in 3 out of the 5 countries (Malaysia, Thailand and the Philippines). In these ASEAN countries we find strong support for the Keynesian view in the long-run. Therefore, in addition to fiscal deficits, the ratio of investment to GDP contributes to the current account deficits. In one country (Indonesia), we find that current account deficits and budget deficits do not follow a joint path.

Moreover, our findings concur with the neoclassical view that government expenditure crowds out private investment. As expected, our findings also indicate

TABLE 4. The Wald test on short-run causality

\begin{tabular}{|c|c|c|c|c|}
\hline \multirow{2}{*}{$\begin{array}{c}\text { Country/ } \\
\text { Dep. Variable }\end{array}$} & \multicolumn{2}{|c|}{$F$-Statistics ( $p$-value) } & \multirow{2}{*}{\multicolumn{2}{|c|}{$\mathrm{ECT}_{t-1}(p$-value $)$}} \\
\hline & $\mathrm{CAD}$ & $\mathrm{D}$ & & \\
\hline \multicolumn{5}{|l|}{ Malaysia } \\
\hline CAD & - & $0.0622(0.8044)$ & $0.0807(0.7779)$ & \\
\hline$-0.4817(0.0145)^{*}$ & & & & \\
\hline $\begin{array}{c}\mathrm{BD} \\
(0.2343)\end{array}$ & $0.4916(0.4876)$ & - & $0.0250(0.8753)$ & -0.1214 \\
\hline $\begin{array}{c}\mathrm{I} \\
(0.0749)^{* *}\end{array}$ & $3.0107(0.0910)^{* *}$ & $0.2874(0.5951)$ & - & 0.3126 \\
\hline Philippines & & & & \\
\hline $\begin{array}{c}\text { CAD } \\
(0.0002)^{*}\end{array}$ & - & $3.5680(0.0668)$ & $4.2225(0.0470) *$ & -0.7130 \\
\hline $\begin{array}{c}\text { BD } \\
(0.7682)\end{array}$ & $0.0819(0.7763)$ & - & $2.9263(0.0955)$ & 0.0254 \\
\hline $\begin{array}{c}\text { I } \\
(0.1442)\end{array}$ & $0.1000(0.7535)$ & $0.2133(0.6469)$ & - & 0.2318 \\
\hline Singapore & & & & \\
\hline $\begin{array}{c}\text { CAD } \\
(0.1701)\end{array}$ & - & $1.5192(0.2330)$ & $0.8012(0.5045)$ & -0.1497 \\
\hline$\frac{\mathrm{BD}}{(0.0034)^{*}}$ & $1.3543(0.2786)$ & - & $1.2895(0.2989)$ & 0.1887 \\
\hline $\begin{array}{c}\mathrm{I} \\
(0.0831)^{* *}\end{array}$ & $0.4599(0.7127)$ & $0.2092(0.8891)$ & - & 0.3036 \\
\hline
\end{tabular}


that investment contributes significantly to the current account deficit. In addition, the results indicate that the ASEAN countries rely on foreign capital to finance their domestic investment, thus suggesting that the Feldstein-Horioka puzzle is less important in the emerging economies.

Most of these countries underwent liberalisation of capital account in the mid-1980, driven by globalisation of financial flows. Together these findings suggest that the large deficit (recorded several years before the crisis) was due to the influx of foreign capital inflows. From a policy perspective, the empirical findings support the argument that government spending in the post-crisis era will affect current account imbalances. Therefore, budget deficits are rightly the concern of policymakers in crisis-inflicted countries with large fiscal deficits. The results also suggest that budget deficit is a weakly exogenous variable (Malaysia, Thailand and the Philippines). Such a finding has a significant policy implication in the context of the ASEAN countries because it would imply that fiscal policies have been effective in controlling the correct account deficits.

\section{ACKNOWLEDGEMENTS}

Part of this study was undertaken while the first author was visiting Washington State University under the Fulbright Program. Financial support from the Malaysian Government [IRPA Grants no: 05-02-04-0532] is gratefully acknowledged. All remaining errors and omissions are those of the authors.

\section{REFERENCES}

Abell, J.D. 1990. Twin deficits during the 1980s: An empirical investigation. Journal of Macroeconomics 12: 81-96.

Ahmed, H. \& Miller, S.M. 2000. Crowding-out and crowding-in effect of the components of government expenditure. Contemporary Economic Policy 18: 124-133.

Anoruo, E. \& Ramchander, S. 1998. Current account and fiscal deficits: Evidence from five developing economies of Asia. Journal of Asian Economics 9: 487-501.

Argimon, I. Gonzalex-Paramo, J.M. \& Roldan, J.M. 1997. Evidence of public spending crowding-out from a panel of OECD countries. Applied Economics 29: 1001-1010.

Bachman, D.D. 1992. Why is the U.S. current account deficit so large? Evidence from vector autoregressions. Southern Economic Journal 59: 232-240.

Bagnai, A. 2006. Structural breaks and the twin deficits hypothesis. International Economics and Economic Policy 3: 137-155.

Bahmani-Oskooee, M. 1995. The long-run determinants of the US trade balance revisited. Journal of Post Keynesian Economics 17: 457-465.

Bahmani-Oskooee, M. 1999. Do federal budget deficits crowd out or crowd in private investment? Journal of Policy Modeling 21: 633-640.

Barro, R.J. 1989. The Ricardian approach to budget deficits. Journal of Economic Perspectives 3: 37-54.

Bernheim, B.D. 1989. A neoclassical perspective on budget deficits. Journal of Economic Perspectives 3: 55-72.

Blanchard, O. \& Giavazzi, F. 2003. Current account deficits in the Euro area. The end of the 
Feldstein-Horioka puzzle? MIT Department of Economics Working Paper No. 03-05. Cheung, Y.W. \& Lai, K.S. 1993. Finite-sample sizes of Johansen's likelihood ratio tests for cointegration. Oxford Bulletin of Economics and Statistics 55: 313-328.

Enders, W. 1995. Applied Econometric Time Series. New York: John Wiley and Sons.

Fidrmuc, J. 2003. The Feldstein-Horioka puzzle and the twin deficits in selected countries. Economics of Planning 36: 135-152.

Gramlich, E.M. 1989. Budget deficits and national saving: Are politicians exogenous? Journal of Economic Perspectives 3: 23-35.

Islam, M. F. 1998. Brazil's twin deficits: an empirical examination. Atlantic Economic Journal 26: 121-128.

Johansen, S. 1995. Likelihood-based inference in cointegrating vector autoregressive models. New York: Oxford University Press.

Johansen, S. 1998. Likelihood analysis of seasonal cointegration. Journal of Econometrics 88: 301-339.

Johansen, S. \& Juselius, K. 1990. Maximum likelihood estimation and inference on cointegration with applications to the demand for money. Oxford Bulletin of Economics and Statistics 52: 169-210.

Kaufmann, S., Scharler, J. \& Winckler, G. 2002. The Austrian current account deficit: Driven by twin deficits of by intertemporal expenditure allocation? Empirical Economics 27: 529-542.

Khalid A.M. \& Teo, G.W. 1999. Causality tests of budget and current account deficits: Cross-country comparisons. Empirical Economics 24: 389-402.

Kouassi, E., Mougoue, M. \& Kymn, K.O. 2004. Causality tests of the relationship between the twin deficits. Empirical Economics 29: 503-525.

Kulkarni, K. G. \& Erickson, E. L. 2001. Twin deficit revisited: Evidence from India, Pakistan and Mexico. Journal of Applied Business Research 17: 97-104.

Kwiatkowski, D., Phillips, P.C.B., Schmidt, P. \& Shin, Y. 1992. Testing the null hypothesis of stationarity against the alternative of a unit root. Journal of Econometrics 54: 159-178.

Miller, S.M. \& Russek F.S. 1997. Fiscal structures and economic growth: International evidence. Economic Inquiry 35: 603-13.

Mohammadi, H. 2004. Budget deficits and the current account balance: New evidence from panel data. Journal of Economics and Finance 28: 39-45.

Nelson, M.A. \& Singh, R.D. 1994. The deficit-growth connection: Some recent evidence from developing countries. Economic Development and Cultural Change 43: 167-191.

Piersanti, G. 2000. Current account dynamics and expected future budget deficits: Some international evidence. Journal of International Money and Finance 19: 255-271.

Rahman, M. \& Mishra, B. 1992. Cointegration of US budget and current account deficits: Twins or strangers? Journal of Economics and Finance 16: 119-127.

Salvatore, D. 2006. Twin deficits in the G-7 countries and global structure imbalances. Journal of Policy Modeling 28: 701-712.

Seater, J.J. 1993. Ricardian equivalence. Journal of Economic Literature 31: 142-190.

Zietz, J. \& Pemberton, D.K. 1990. The US budget and trade deficits: A simultaneous equation model. Southern Economic Journal 57: 23-34.

Hamizun Ismail

Faculty of Science and Technology

Universiti Kebangsaan Malaysia 
Malaysia

Email: hamizun@ukm.my 